\title{
Immunomodulatory Actions of Mesenchymal Stromal Cells (MSCs) in Osteoarthritis of the Knee
}

\author{
Gangireddi Suresh Babu 1,2,3, Yelisetty Badrish 4, Vinit M Oswal ${ }^{5}$, Naveen Jeyaraman 2,3,6, \\ Gollahalli Shivashankar Prajwal 2,3,7, Madhan Jeyaraman 2,8,9,10,*(D), Sathish Muthu 2,8,9,11,*(D) \\ and Manish Khanna ${ }^{2,12}$
}

check for

updates

Citation: Babu, G.S.; Badrish, Y.; Oswal, V.M.; Jeyaraman, N.; Prajwal, G.S.; Jeyaraman, M.; Muthu, S.;

Khanna, M. Immunomodulatory Actions of Mesenchymal Stromal Cells (MSCs) in Osteoarthritis of the Knee. Osteology 2021, 1, 209-224. https: / / doi.org/10.3390/ osteology1040020

Academic Editor: Jan Zabrzyński

Received: 3 September 2021

Accepted: 16 November 2021

Published: 17 November 2021

Publisher's Note: MDPI stays neutral with regard to jurisdictional claims in published maps and institutional affiliations.

Copyright: (C) 2021 by the authors. Licensee MDPI, Basel, Switzerland. This article is an open access article distributed under the terms and conditions of the Creative Commons Attribution (CC BY) license (https:// creativecommons.org/licenses/by/ $4.0 /)$.
1 Department of Orthopaedics, M S Multi Speciality Hospital, Pithapuram, East Godavari 533450, Andhra Pradesh, India; gangisb@gmail.com

2 Indian Stem Cell Study Group (ISCSG) Association, Lucknow 226010, Uttar Pradesh, India; naveenjeyaraman@yahoo.com (N.J.); prajwalgs1894@gmail.com (G.S.P.); manishvenus@rediffmail.com (M.K.)

3 Research Fellow, Fellowship in Orthopaedic Rheumatology (FEIORA), Dr. Ram Manohar Lohiya National Law University, Lucknow 226010, Uttar Pradesh, India

4 Department of Orthopaedics, Dr Badrish's Jaya Orthopaedic Hospital, Nandyal, Kurnool 518501, Andhra Pradesh, India; badrishyelisetty@gmail.com

5 Department of Orthopaedics, Spire Clinic, Bengaluru 560055, Karnataka, India; vinitz09@gmail.com

6 Department of Orthopaedics, Atlas Hospitals, Tiruchirappalli 620002, Tamil Nadu, India

7 Department of Orthopaedics, Mallika Spine Centre, Guntur 522002, Andhra Pradesh, India

8 Department of Biotechnology, School of Engineering and Technology, Sharda University, Greater Noida 201306, Uttar Pradesh, India

9 Orthopaedic Research Group, Coimbatore 641001, Tamil Nadu, India

10 Department of Orthopaedics, Faculty of Medicine, Sri Lalithambigai Medical College and Hospital, Chennai 600095, Tamil Nadu, India

11 Department of Orthopaedics, Government Medical College and Hospital, Dindigul 624001, Tamil Nadu, India

12 Department of Orthopaedics, Prasad Institute of Medical Sciences, Lucknow 226010, Uttar Pradesh, India

* Correspondence: madhanjeyaraman@gmail.com (M.J.); drsathishmuthu@gmail.com (S.M.)

\begin{abstract}
Cellular therapy offers regeneration which curbs osteoarthritis of the knee. Among cellular therapies, mesenchymal stromal cells (MSCs) are readily isolated from various sources as culture expanded and unexpanded cellular population which are used as therapeutic products. Though MSCs possess a unique immunological and regulatory profile through cross-talk between MSCs and immunoregulatory cells (T cells, NK cells, dendritic cells, B cells, neutrophils, monocytes, and macrophages), they provide an immunotolerant environment when transplanted to the site of action. Immunophenotypic profile allows MSCs to escape immune surveillance and promotes their hypoimmunogenic or immune-privileged status. MSCs do not elicit a proliferative response when co-cultured with allogeneic T cells in vitro. MSCs secrete a wide range of anti-inflammatory mediators such as PGE-2, IDO, IL-1Ra, and IL-10. They also stimulate the resilient chondrogenic progenitors and enhance the chondrocyte differentiation by secretion of BMPs and TGF $\beta 1$. We highlight the various mechanisms of MSCs during tissue healing signals, their interaction with the immune system, and the impact of their lifespan in the management of osteoarthritis of the knee. A better understanding of the immunobiology of MSC renders them as an efficient therapeutic product for the management of osteoarthritis of the knee.
\end{abstract}

Keywords: osteoarthritis; mesenchymal stromal cells; immunotolerant; immunobiology

\section{Introduction}

Osteoarthritis of the knee, also called degenerative arthritis or osteoarthrosis, is a multi-factorial, slowly progressing disease of the synovial joint [1]. It is primarily a noninflammatory degenerative disorder of the knee which is characterized by the progressive degenerative process leading to irreversible articular cartilage destruction [1,2]. Among all musculoskeletal diseases, osteoarthritis of the knee poses significant health, economic and 
social burden to the aging population, hence it is prudent to exactly define and locate the etiological agent to contemplate an effective management strategy [3]. A total of $15 \%$ of the world population is affected with osteoarthritis of the knee which leads to the major cause of activity limitation [4]. Understanding the molecular and cellular components of the pathophysiology of osteoarthritis of the knee is of paramount importance to establish the cell-based therapy to formulate the disease-modifying strategy [2,5].

Osteoarthritis of the knee results due to degradation of the articular cartilage and the components of the bone matrix [4]. The earliest pathomechanism in the progression of cartilage loss is due to the loss of type 2 collagen and aggrecans in the cartilage tissue [6]. In the early stage of knee osteoarthritis, natural killer (NK) cells and macrophages play a significant role in pathogenesis and intervening these cross-talks pose a potential breakthrough in the management of osteoarthritis of the knee [7]. Osteoarthritis of the knee is characterized by increased levels of pro-inflammatory cytokines such as IL-1 and TNF$\alpha$, raised expression of TGF- $\beta$, and the activation of matrix metalloproteinases (MMPs), ultimately leading to chondrocyte senescence $[8,9]$.

Cytotherapy or cell-based therapies have been developed in the past decade for management of early knee osteoarthritis by utilizing the stem cells harvested from various donor tissues such as bone marrow, adipose tissue, placenta, synovium, dental tissues, peripheral blood, and rarely from embryonal tissues [10,11]. In particular, mesenchymal stromal cell (MSC)-based cellular therapy demonstrate a promising tool for regenerating the degenerated cartilage in the osteoarthritic knee [12-15]. A large number of published literature states that the regenerative capacity of MSCs is due to paracrine factors released by MSCs rather than the pluripotent nature of MSCs to differentiate into cells of the desired tissue $[16,17]$. The ease of availability from multiple sources makes MSCs the versatile cell-based therapy of choice in regenerating tissues [18]. Despite the promising results seen in vitro and in vivo studies, the application of MSCs are limited due to the risk of teratoma formation, limited viability of differentiated cells and rejection of the cells post transplantation [19-22].

There is no available evidence to prove that engrafted MSCs in osteoarthritis of the knee are differentiated into cartilage cells. These engrafted MSCs work in a paracrine fashion and stimulate the tissue-specific residual and resilient cells for tissue regeneration and repair [23,24]. MSCs act by empowerment rather than replacement $[25,26]$. The engrafted MSCs possess a stromal environment that contains both cellular and molecular components. ${ }^{26}$ The combined action of cytokines and chemokines drive MSC to induce tissue regeneration by proliferation and differentiation of resident stem cells [27].

\section{Immunomodulation by Living MSCs}

Immunomodulation by MSCs is through direct cell-to-cell contact (membrane-bound proteins and receptors) and by paracrine signaling of macromolecules (cytokines, chemokines, and trophic factors) in the environment [28]. Interleukin-10 (IL-10) is a pleiotropic immunomodulatory cytokine that regulates innate and adaptive immune systems. The interplay between regulatory cytokines and IL-10 establishes a tolerogenic environment suitable for the inhibition of T-cells. IL-10 plays a significant positive feedback loop by enhancing proliferative and molecular changes when MSCs are infused [29,30].

MSCs exhibit a varied spectrum of immunoregulatory capabilities in both innate and adaptive immune systems. Due to the prevailing inflammatory environment, specific toll-like receptor (TLR) ligands affect the MSC-based cellular therapy in the management of osteoarthritis of the knee [31-33]. In the early stages of knee osteoarthritis, TLR2/4 on MSC surface may result in polarization into MSC1, which promotes further immunogenic response to protect joint tissues in osteoarthritis pathogenesis [32]. In later stages of knee osteoarthritis of the knee, TLR3 accumulation leads to polarization into MSC2 which further prevents articular surface damage in the osteoarthritis of the knee [32]. Failure of inflammatory attenuation leads to the continuation of the vicious cycle in osteoarthritis pathogenesis. 
In such a pro-inflammatory milieu, the quiescent resident MSCs are attenuated and may not be induced in the lines of regeneration of the articular cartilage and hence infusion of MSCs into the knee joint may not only repair and regenerate the joint cartilage but also help in stimulating the resident MSCs to attain joint homeostasis in favor of regeneration. MSCs suppress host immune responses by inhibiting immune cells proliferation and maturation in a non-MHC restricted manner [34]. MSCs are considered to be hypoimmunogenic, which express low levels of HLA 1 and are deprived of HLA class II and co-stimulatory molecule expression [35,36]. Numerous studies have also demonstrated MSCs to suppress the activity of a broad range of immune cells, including T cells, natural killer (NK) cells, dendritic cells DCs), B cells, neutrophils, monocytes, macrophages [37].

\section{Immunomodulation by Apoptotic MSCs}

There is no consensus on the viability of MSCs to exert immunomodulatory effects in the local or systemic environment. Once administered, MSCs undergo radical biological and morphological changes and disappear from the site of injection within a few days of intra-articular injection [38]. Despite the disappearance of administered MSCs from the site, they elaborate the cytokines and chemokines which work by paracrine signaling and induce the quiescent and resident MSCs to enhance the significant therapeutic effects [23]. Hence the dead MSCs exert a non-specific immunomodulatory environment in the osteoarthritis of the knee through apoptosis, complement-mediated cell death, autophagy, and senescence [39]. The paracrine and the contact immunomodulatory effects of MSCs on the immune cells are given in Figures 1 and 2 respectively.

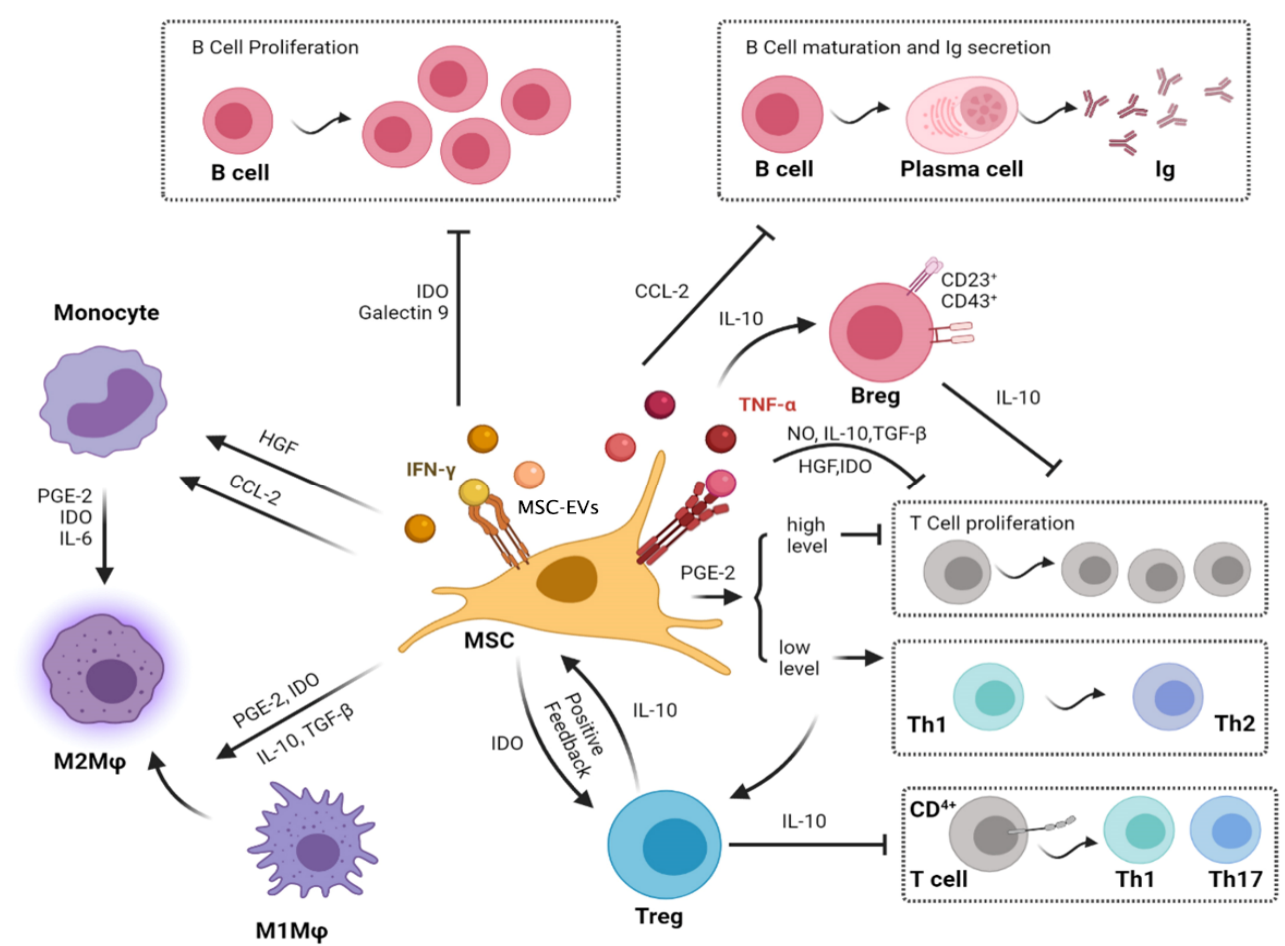

Figure 1. Paracrine immunomodulatory effects of the mesenchymal stromal cell on immune cells. [Note: MSCs have their immunomodulatory effects on Macrophages, T cells, and B cells related to osteoarthritis via the secretion of various cytokines through MSC-derived exosomal vesicles. MSCs inhibit the migration of macrophages and regulate their polarization by inducing transformation from M1 to M2. MSCs inhibit the proliferation of T cells and activation of inflammatory TH1 and TH17 cells. In turn, MSCs induce immunosuppressive Tregs. Moreover, MSCs decrease B-cell activation and proliferation and attenuate immunoglobulin production]. 

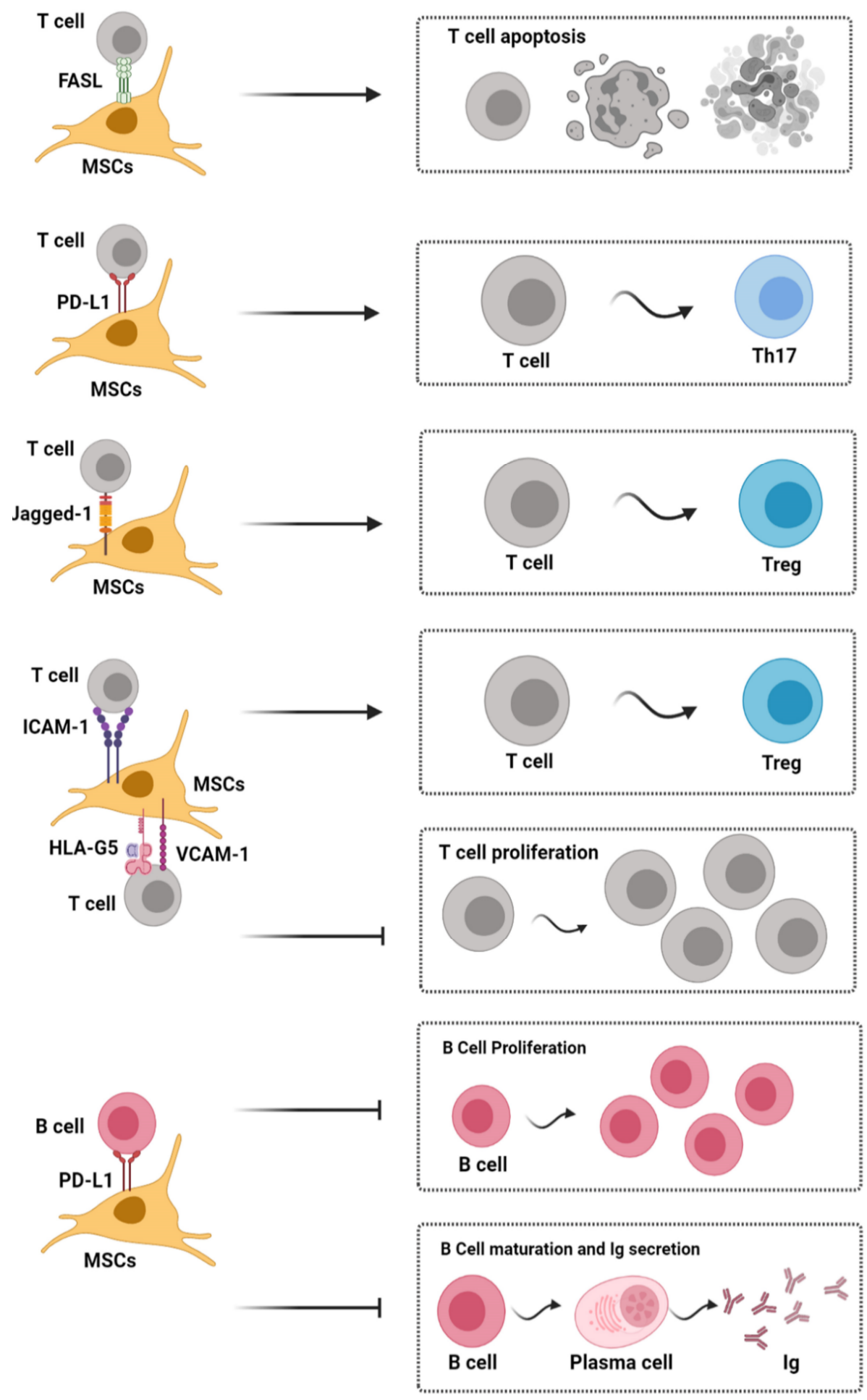

Figure 2. Contact dependent immunoregulatory effects of mesenchymal stromal cells on immune cells. [Note: Fas/FasL signal activation induces apoptosis of inflammatory T cells; Jagged-1/Notch-1 signal activation can induce CD4+ T cells to differentiate into Tregs, and PD-1/PD-L1 signaling effectively represses TH17 differentiation and inhibits the proliferation and maturation of B cells. Moreover, HLA-G5, ICAM-1, and VCAM-1 are also needed for MSCs to exert their immunosuppressive effects upon T cells]. HLA-G5, human leukocyte antigen-G5; ICAM-1, intercellular adhesion molecule-1; Ig, immunoglobulin; MSC, mesenchymal stem cells; PD-L1, programmed death-1 ligand; Th, helper T cell; Treg, regulatory T cell; VCAM-1, vascular cell adhesion molecule-1. 
Apoptotic MSCs interact with immune cells directly by apoptosis and indirectly by phagocytosis. In DIRECT mechanism, apoptotic or dead MSCs create an immunosuppressive or immune-privileged environment by secreting IL-10 and TGF- $\beta$ and inhibit lipopolysaccharide (LPS) stimulated macrophages by the secretion of IL-1 $\beta$ and TNF- $\alpha$ [40]. In INDIRECT mechanism, phagocytes eliminate MSCs resulting in hyporesponsiveness to LPS and switching off the immunological cellular environment to an anti-inflammatory environment [30]. Upon cell-to-cell contact, $\mathrm{T}$ cells release perforin and granzyme $\mathrm{B}$ and induce apoptosis of infused MSCs [41]. IDO, a soluble factor, secreted by phagocytes is responsible for immunomodulation [42]. Mancuso et al. emphasized that apoptotic MSCs retrieved from osteoarthritis of the knee exhibited higher immunosuppressive effects than viable MSCs [42].

Complement cascade induces phagocytosis and recruits progenitor cells to the site of injury. Complement systems exhibit an interplay between MSCs to influence the biological features of engrafted cells. When a complement molecule binds to MSC, it induces phagocytosis by macrophages and in turn, M2 polarization occurs to establish a tolerogenic environment [43]. With the rapid clearance of MSCs from the systemic circulation, a therapeutic response being observed was due to the interplay between complement and monocyte-phagocyte system [44]. During normal development, autophagy modulate cellular homeostasis and remodeling potential. MSCs attenuate autophagy and promote cellular survival, proliferation, differentiation, and restoration of functional tissues in the degenerative environment [45]. Senescent (aged) MSCs exhibit minimal proliferation, differentiation, immunoregulatory and secretory ability in osteoarthritis of the knee [46].

Breg, regulatory B cell; CCL-2, C-C motif chemokine ligand 2; HGF, hepatocyte growth factor; IDO, indoleamine-2,3-dioxygenase; IL, interleukin; Ig, immunoglobulin; IFN- $\gamma$, interferon-gamma; MSC, mesenchymal stromal cell; MSC-EVs, Mesenchymal stromal cell-derived exosomal vesicles; $\mathrm{M} \varphi$, macrophages; NO, nitric oxide; PGE2, prostaglandin E2; Th, helper T cell; Treg, regulatory T cell; TGF- $\beta$, transforming growth factor-beta.

\section{Effect of MSCs on Macrophages}

The most responsible cellular component for the immunogenic environment in knee joint is synovial macrophage $(\mathrm{M} \varphi)$ [43]. Once MSCs are administered, proinflammatory macrophages $(\mathrm{M} 1 \mathrm{M} \varphi)$ are activated by IFN- $\gamma$ and TNF- $\alpha$ polarise to anti-inflammatory macrophages $(\mathrm{M} 2 \mathrm{M} \varphi)$ which releases soluble factors and downregulate inflammatory and apoptotic events in cartilage which in turn upregulate the chondrogenic regeneration and remodeling [47-49]. Wu et al. studied the cartilage damage by the production of cytokine storm in macrophage Fas-induced apoptosis transgenic mice [50]. Various evidences demonstrate the polarization of macrophages $[\mathrm{M} 1 \mathrm{M} \varphi \rightarrow \mathrm{M} 2 \mathrm{M} \varphi]$ induces the enhancement of cartilage tissue regeneration when MSCs are transplanted [51-54].

The secretome analysis exhibit that MSCs affect macrophage polarization, proliferation, and migration. Macrophage polarization $(\mathrm{M} 1 \rightarrow \mathrm{M} 2)$ promotes the healing process of injured cartilage in the Osteoarthritis of the knee [47]. Gradual conversion of M1 macrophage (fried egg-like) into M2 macrophage (spindle-like) when co-cultured with MSCs is accompanied by increased levels of IL-10, phagocytosis and decreased levels of IL-12 and IL-1 $\beta$ [54]. Macrophage polarization by MSCs are exhibited through direct cell-to-cell contact and cytokine secretion such as IL-10, PG-E2, IDO, and TGF- $\beta$ [55-57]. Evidences prove that MSC induces polarization of macrophages, decreases pro-inflammatory cytokines, increases anti-inflammatory cytokines, inhibits joint degeneration, and promotes repair and regeneration of damaged cartilaginous tissues [48,58,59]. The anti-inflammatory response of MSCs through macrophages is via COX-2/PGE2/EP4 axis [60]. MSCs harness macrophage-derived amphiregulin (AREG), an epidermal growth factor receptor, to maintain tissue homeostasis [61]. 


\section{Effect of MSCs on T Cells}

$\mathrm{T}$ lymphocytes represent the second line cellular constituent among the synovial cellular population in the osteoarthritis of the knee. MSCs inhibit the proliferation of T cells in a dose-dependent manner. Helper $\mathrm{T}\left(\mathrm{CD}^{+}\right)$and cytotoxic $\mathrm{T}\left(\mathrm{CD} 8^{+}\right)$cells are involved in the pathogenesis of Osteoarthritis of the knee $[62,63]$. In osteoarthritis of the knee, the synovial cellular population exhibit higher levels of $\mathrm{CD} 4^{+} \mathrm{IFN}-\gamma^{+} \mathrm{T}$ cells $\left(\mathrm{T}_{\mathrm{H}} 1\right), \mathrm{CD} 4^{+} \mathrm{IL}-17^{+}$ T cells $\left(\mathrm{T}_{\mathrm{H}} 17\right)$, and $\mathrm{CD} 8^{+} \mathrm{T}$ cells $\left(\mathrm{T}_{\mathrm{C}}\right)$, and synovial fluid exhibit higher levels of $\mathrm{CD} 4^{+} \mathrm{IL}-$ $17^{+} \mathrm{T}$ cells $\left(\mathrm{T}_{\mathrm{H}} 17\right)$ and CD4 ${ }^{+}$IL- $9^{+} \mathrm{T}$ cells $\left(\mathrm{T}_{\mathrm{H}} 9\right)[64,65]$. The cross-talk among $\mathrm{T}_{\mathrm{H}} 1$ cells (IL-2, IFN- $\gamma$, TNF- $\alpha$, lymphotoxins, and GM-CSF), $\mathrm{T}_{\mathrm{H}} 9$ cells (IL-9), and $\mathrm{T}_{\mathrm{H}} 17$ cells (IL-17 and -23) aggravates cartilage degeneration and chondrocyte loss $[66,67] . T_{C}$ cells' role in the pathophysiology of Osteoarthritis of the knee is still unclear. Osteoarthritis patients demonstrate a few $\mathrm{CD} 8^{+} \mathrm{T}$ cells and a higher $\mathrm{CD} 4^{+}: \mathrm{CD} 8^{+}$ratio [68]. Both in peripheral blood and synovial fluid, osteoarthritis patients possess $\mathrm{CD}^{+} \mathrm{CD}^{2} 5 \mathrm{RA}^{+}, \mathrm{CD}^{+} \mathrm{CD} 29^{+}$, and $\mathrm{CD}^{+} \mathrm{S}_{6 \mathrm{~F}} 1^{+}$cells [69]. In the ACL transected osteoarthritis mice model, the number of activated $\mathrm{CD}^{+} \mathrm{T}$ cells was significantly higher than the sham group [70]. Chondrocyte loss occur more slowly in $\mathrm{CD}^{+} \mathrm{T}$ cell knockout mice than in wild-type mice [70].

With the addition of TGF- $\beta$, naïve T cells are induced and differentiated into Treg cells which maintain immunological tolerance by secreting IL-10 and -35 [71,72]. Various studies have proved that Tregs have a protective role in osteoarthritis of the knee. MSC-derived cytokines induce $\mathrm{T}$ cell apoptosis and inhibit the naïve $\mathrm{T}$ cell activation and differentiation of $\mathrm{T}$ cells to various subsets [73]. Upon adding MSCs in denuded cartilage, enhanced production of IL-10 favor the microenvironment to secrete sHLA-G5 which attenuates the activation of $\mathrm{CD}^{+} \mathrm{T}$ cells to $\mathrm{T}_{\mathrm{H}} 1$ and $\mathrm{T}_{\mathrm{H}} 17$ thereby inducing the production of Treg cells and a positive feedback loop [74-76].

Nitric oxide secreted by MSCs regulates T cell immunosuppressive response through cell cycle arrest, apoptosis, complement-dependent killing, or autophagy [37]. Downregulation of cyclin D2 expression and upregulation of p27kip1 expression in T cells through TGF- $\beta$ and HGF secreted by MSCs leads to cell cycle arrest in the G1 phase and inhibits T cell proliferation [77]. Downregulation of IL-2 receptor leads to inhibition of T cell proliferation through PGE2 secreted by MSCs and results in impairment of DNA binding activity through JAK-3 signaling inhibition [78]. Direct contact between MSC and T cell enhance immune-regulation of T cells. Enhanced expression of ICAM-1 and VCAM-1 molecules over MSCs exert immunosuppressive effects through T cells [79,80]. Fas ligand signaling pathway activates the apoptosis of T cells, Notch-1 signaling promote differentiation of naïve $T$ cell to Treg cells, and PD-L1 signaling represses $\mathrm{T}_{\mathrm{H}} 17$ differentiation [81-83]. sHLA-G5 play a major role in cell-to-cell contact and paracrine functions of MSCs. [84]

\section{Effect of MSCs on B Cells}

B lymphocytes are the key mediators for the adaptive humoral immune system, which are characterized by antigen presentation and antibody production. MSCs reduce the $B$ cell population by arresting the proliferation of B cells in the G0/G1 phase of the cell cycle [85]. MSCs inhibit the differentiation of B cells and significantly impair the production of antibodies $[86,87]$. Both cell-to-cell contact mechanisms and soluble factors secreted by MSCs play a significant role in B cell suppression in the cartilage environment. Upon activation of MSCs by IFN- $\gamma$, the upregulation of galectin- 9 resulted in anti-proliferative and immunosuppressive effects of B and T cells [88]. MSCs affect the chemotactic property of $\mathrm{B}$ cells by modulating the adhesion molecules and the receptors and enhancing the downregulation of CXCL13/CXCR5 ligand [89,90].

MSC co-culture enhances the immunomodulatory activity of B cells by upregulating anti-inflammatory cytokines. MSCs induce the production of Bregs cells $\left(\mathrm{CD} 23^{+} \mathrm{CD} 43^{+}\right)$ which inhibit the secretion of pro-inflammatory cytokines and $\mathrm{T}$ cell proliferation through IL-10 dependent pathway [91,92]. MSCs inhibit STAT-3 factor via C-CL2 motif and induce PAX-5 protein synthesis to inhibit the production of immunoglobulins by plasma cells [93]. 
With an increased expression of IFN- $\gamma$, MSCs activate the PL-L1 signaling pathway to inhibit the proliferation and maturation of B cells [94].

Direct interaction of MSCs with B cells reduces plasmablast formation and induces the enhancement of Breg cells formation [30]. Breg cells accelerate the immunological tolerance through immunosuppressive cytokines and mediators [95]. Bregs secrete IL-10 which converts effector $\mathrm{CD}^{+} \mathrm{T}$ cells into Foxp3+ Tregs [96]. In the presence of IFN- $\gamma$ secreted by T cells, MSCs can inhibit B cell proliferation [30]. These Breg cells attenuate joint inflammation and cartilage degradation in osteoarthritis of the knee.

\section{Effect of MSCs on NK Cells}

Natural Killer (NK) cell form an integral part of the immune system that bridge the adaptive immune system with the innate immune system. Upon NK cell activation, cell-mediated immune responses are enhanced by both helper $\mathrm{T}$ and cytotoxic $\mathrm{T}$ cells [97]. Soluble factors (TGF- $\beta$ and PGE2) secreted by MSCs attenuate NK cell functions and inhibit the proliferation of NK cells [98]. Spaggiari et al. demonstrated the antiproliferative activity and inhibition of cytotoxicity and cytokine production in the in-vitro cross-talk between MSCs and NK cells [99]. MSCs pose an inhibitory effect on NK cells by enhancing the expression of activating NK cell receptors (NKp30, NKp44, and NKG2D) $[99,100]$. IDO and PGE2 secreted by MSCs are the key factors which are responsible for MSC mediated inhibition of NK cell proliferation [99].

Interleukin-2 activated NK cells induce the apoptosis of MSCs which demonstrates low-level activity of HLA class 1 antigens [101,102]. MSC-derived TGF- $\beta 1$ inhibits NK cell proliferation thereby reducing its cytotoxic and antiproliferative activity in the desired environment [103]. NK cell-mediated IFN- $\gamma$ release enhanced by MSCs provide anti-infective activity at the injury site and affect tissue regeneration [104,105]. In osteoarthritis of the knee patients, NK cells expressed pro-inflammatory protease granzyme A whereas, in the synovium cellular population, increased levels of CD56(+)/CD16(-) cells were found $[106,107]$. Jaime et al. found the immunoregulatory phenotype of NK cell $\left[\mathrm{CD} 56(+)^{\text {bright }} / \mathrm{CD} 16(-)^{\mathrm{dim}}\right]$ in the synovial fluid of Osteoarthritis of the knee [107].

\section{Effect of MSCs on Dendritic Cells}

Dendritic cells (DC) can stimulate naïve and memory $\mathrm{T}$ cells in the body. DC cells are derived from bone marrow CD34+ cells in vivo or stimulated by GM-CSF and IL-4 from monocytes in vitro or from CD34+ hematopoietic progenitors in presence of GMCSF and TNF- $\alpha[108,109]$. DC cells enhance, primary immune tolerance and present antigens to naïve T cells, memory T cells, B cells, and NK cells [110]. MSCs affect the recruitment, maturation, and homing of DCs. Human MSCs significantly reduce the monocyte differentiation into DCs [by decreasing the upregulation of CD-80, $-86,-1 \mathrm{a},-83$, -40 , and HLA-DR] [111]. When DCs are co-cultured with MSCs, they induce Th2 and Tregs cells which result in the suppression of pro-inflammatory T cell activation [112]. MSCs induce the maturation of type 1 DCs to decrease TNF- $\alpha$ and type 2 DCs to increase IL-10 by creating anti-inflammatory or immunotolerant phenotype [113].

\section{Effect of MSC-Derived Extracellular Vehicles (EVs) on Osteoarthritis of the Knee}

MSC-derived extracellular vesicles (EVs) are involved in tissue repair, immunomodulation, proliferation, anti-tumorigenic, and regeneration [114-116]. Based on biogenesis and size, EVs are classified into exosomes (30-150 nm endosome-derived plasma membrane-coated vesicles), microvesicles (100-1000 nm non-endocytic origin vesicles), and apoptotic bodies (1-5 $\mu \mathrm{m}$ vesicles released by apoptotic cells) [117]. EV markers are ALG-2-interacting protein X (Alix), tetraspanin proteins CD9, CD63, CD81 and heatshock protein (Hsp)-60, -70, and -90 [118-120]. MSC-released EVs express unique surface antigens including CD44, CD73, CD90 and CD105 [121]. The molecular composition of these extracellular vehicles includes endosome-associated proteins (Rab GTPase, SNAREs, annexins, flotillin, Tsg101), membrane proteins (CD-63, -81, -82, -53 \& -37), lipid raft 
protein (glycosylphosphatidylinositol-anchored protein) and RNA (sRNAs, miRNA, fragments of tRNA, Y-RNA, and siRNAs) [122-125]. The cross-talk between MSCs and the neighboring diseased micromolecular tissue environment is the zone of MSC-sEV based therapeutics [126,127].

MSC exosomes mediate angiogenesis via regulation of the NF- $\mathrm{kB}$ signaling pathway and miR-494 [128,129]. MSC-derived EVs modulate the immune system by induction of anti-inflammatory cytokines and Treg cells, by inhibition of B lymphocytes, regulation of macrophage polarization, and mobilization of neutrophils [130-132]. Exosome-induced macrophages lead to Treg cell expansion by secretion of more IL-10 as compared to the macrophages induced by lipopolysaccharide $[133,134]$. miR-146a enhances macrophage polarization to anti-inflammatory M2 macrophages $[135,136]$. Galectin-1, endogenous leptin on the EV surface, was also found to be involved in the immunosuppressive effects on T lymphocytes [137].

Exosomes are a potential candidate as early diagnostic markers to identify clinical osteoarthritis and cancer based on the exosome-specific proteins [138,139]. Moreover, miRNAs and lncRNAs of the exosomal structure have been considered as potential diagnostic markers for diseases like rheumatoid arthritis and osteoarthritis [140-146]. MSC-exosomes prevent cartilage degeneration and downregulate the expression of tartrate-resistant acid phosphatase (TRAP) expression and RANKL-RANK-TRAF6 signaling activation to promote remodeling of subchondral bone [147-151]. A significant reduction in miRNA-92a-39 and miRNA-95-5p was observed in osteoarthritis chondrocytes [143,152]. An increased miRNA-145 and -221 derived from adipose tissue-derived stem cells favor chondrogenesis and suppress the expression of pro-inflammatory cytokines and promote the degenerated cartilage for repair and regeneration. Exosomal lncRNA PCGEM1 demonstrated a positive correlation with the WOMAC score and exhibit a significant difference between the early and late stages of osteoarthritis of the knee. These EVs modulate the repair and regeneration of denuded cartilage [153]. There is a temporal association between inflammation (hsCRP) and chondrocyte hypertrophy (COL-X) through HIF-2 $\alpha$ [154]. A negative correlation was observed between COMP and duration of osteoarthritis \& a positive correlation between COMP and age. The versatility of EVs enhances intracellular signaling and shuttling and proceeds to maintain micromolecular homeostasis. The actions of MSC-derived exosomes on the osteoarthritis of the knee are tabulated in Table 1.

Table 1. Summary of the actions of MSC-derived exosomes on osteoarthritis of the knee.

\begin{tabular}{|c|c|c|c|}
\hline Type of Exosomal Cargo & Source of MSCs & Animal Model & Function \\
\hline CD-9 and -63 , TSG101 [155] & Sy-MSCs \& iPSCs & Mice & Induce the chondrocyte migration and proliferation \\
\hline miR-92a-3p [156] & MSCs & Mice & Modulate cartilage development and homeostasis via WNT5A inhibition \\
\hline miR-320c [157] & BM-MSCs & In-vitro & Downregulate MMP-13 and upregulate SOX-9 expression \\
\hline miR-140-Sp [158] & Sy-MSCs & Rat & $\begin{array}{c}\text { Improve the proliferation and migration of articular chondrocytes and prevent } \\
\text { the development of OA }\end{array}$ \\
\hline lncRNA-KLF3-AS1 [159] & MSCs & Rat & Inhibit IL-1 $\beta$ induced chondrocyte apoptosis \\
\hline ??Unknown [160] & MSCs & Rabbit & $\begin{array}{l}\text { Inhibit the phosphorylation of p38 and ERK and induce the phosphorylation of } \\
\text { Akt }\end{array}$ \\
\hline ??Unknown [147] & MSCs & Rat & $\begin{array}{l}\text { Improve the synthesis of GAGs by IL- } 1 \beta \text { and inhibits the IL-1 } \beta \text { induced NO and } \\
\text { MMP-13 production }\end{array}$ \\
\hline ??Unknown [161] & AD-MSCs & In-vitro & $\begin{array}{l}\text { Decrease the generation of inflammatory mediators such as TNF- } \alpha, \text { IL-6, PGE2, } \\
\text { and NO and improve the generation of the anti-inflammatory cytokine IL-10 }\end{array}$ \\
\hline ??Unknown [162] & AD-MSCs & In-vitro & $\begin{array}{l}\text { Downregulate the SABG activity and. Reduce the generation of inflammatory } \\
\text { mediators }\end{array}$ \\
\hline ??Unknown [163] & BM-MSCs & Mice & $\begin{array}{l}\text { Induce the type II collagen, and aggrecan expression, inhibit the expression of } \\
\text { the MMP-13, ADAMTS5, and iNOS }\end{array}$ \\
\hline ??Unknown [164] & ESCs & Mice & $\begin{array}{l}\text { Augment the synthesis of collagen type II and reduce the expression of } \\
\text { ADAMTS5 in the presence of IL-1 } \beta\end{array}$ \\
\hline
\end{tabular}

[AD-MSCs-Adipose tissue-derived mesenchymal stromal cells; BM-MSCs-Bone marrow-derived mesenchymal stromal cells; ESCsEmbryonic stem cells; iPSCs-Induced pluripotent stem cells; MSCs-Mesenchymal stromal cells; Sy-MSCs—Synovium derived mesenchymal stromal cells]. 


\section{Integrative Factors in Immunomodulation of MSCs}

MSCs possess low immunogenicity which makes the cellular mixture possible for either autologous or allogeneic transplantation. MSCs have a profound potential to inhibit the activity of $\mathrm{CD}^{+}$and $\mathrm{CD} 8^{+} \mathrm{T}$ cells, B cells, to inhibit the proliferation of natural killer (NK) cells and maturation of dendritic cells thereby suppressing the production of immunoglobulins $[165,166]$. MSCs stimulate and enhance the proliferation of Treg cells by secretion of soluble factors [TGF- $\beta$, HGF, iIDO, sHLA-G5, PGE2, IL-6, -10, and $\mathrm{TNF} \alpha$-stimulated gene protein-6] [167]. MSCs inhibit the proliferation of lymphocytes, alter the reactivity of lymphocytes to target cells, and prolong the cellular graft survival when infused in a patient with a mismatched MHC group [168]. Soluble factors like TGF- $\beta$ and HGF inhibit the proliferation of $\mathrm{T}$ cells when monoclonal antibodies are added to the system. Hence these factors enhance the naïve $\mathrm{T}$ cell to differentiate into Treg cells to improve the immune tolerance. IDO secreted by MSCs primed with IFN- $\gamma$ attenuates the T cell response to auto- and alloantigens and inhibits the proliferation of $\mathrm{T}$ cells by secreting kynurenine [169]. sHLA-G5 secreted by MSCs suppress the functions of T lymphocytes and NK cells and enhances the expansion of $\mathrm{CD} 4^{+} \mathrm{CD} 25^{\text {high }} \mathrm{FOXP} 3^{+}$Treg cells [170].

With the secretion of PGE2, MSCs regulate adaptive immune responses and induce dendritic cells to upregulate the genes responsible for the secretion of anti-inflammatory cytokines [165]. Further inhibition of T lymphocytes was facilitated by IL-6, nitric oxide, galectin-1, leukemia inhibitory factor (LIF), and semaphorin 3A [171]. LIF promotes and enhances the proliferation and maintenance of Treg cells [172]. MSCs modulate proinflammatory M1 (classical-activated macrophage) phenotype to anti-inflammatory M2 (alternative-activated macrophage) phenotype [60]. The concentration of NO secretion converts the environment into immunoenhancement or immunosuppression [173]. The level of iNOS/IDO plays a critical role in determining the pathophysiological and immunomodulatory roles of MSCs [32].

\section{Cross-Talk between MSCs and Immunological Cells in Cartilage Regeneration}

The immunomodulatory effect of MSCs on the immune cells in the osteoarthritis of the knee is given in Figure 3.

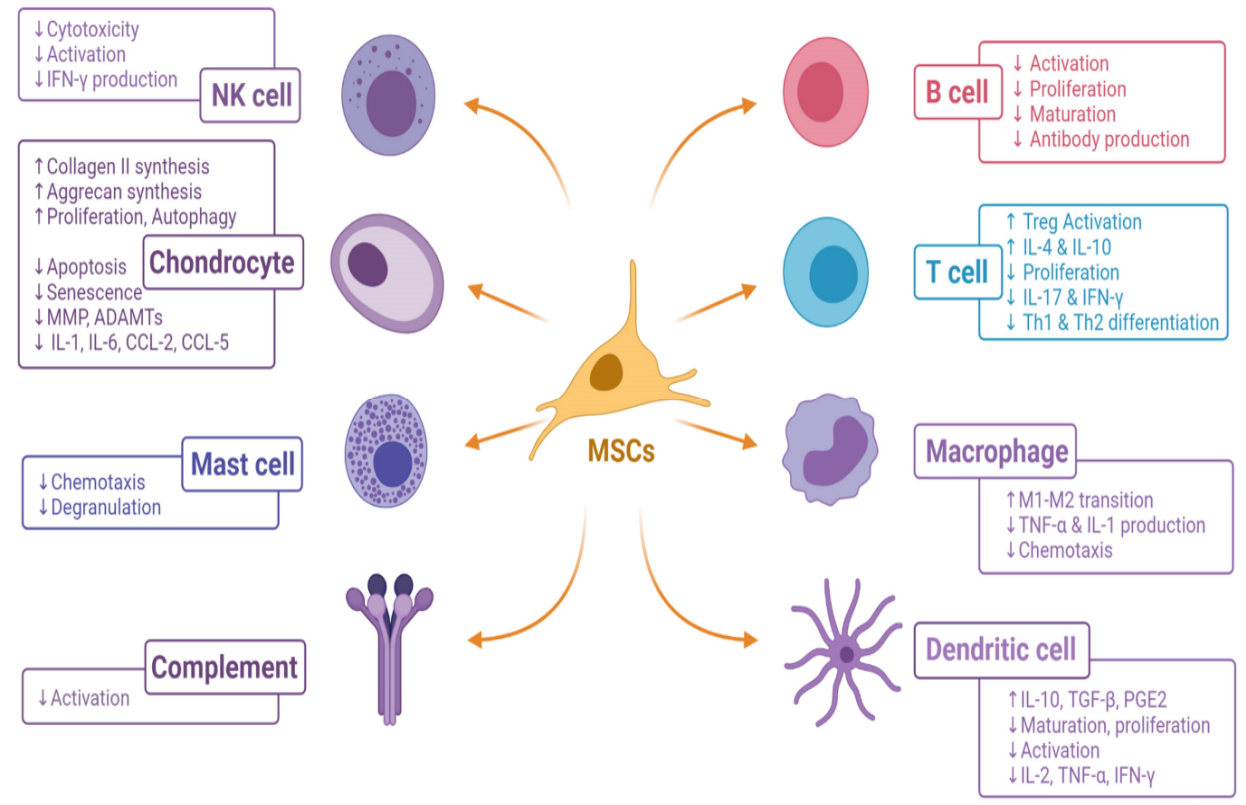

Figure 3. Immunomodulatory effects of MSCs on immune cells in osteoarthritis of the knee. [ADAMTs, A Disintegrin and Metalloproteinase with Thrombospondin motifs; CCL, C-C motif chemokine ligand; IL, interleukin; IFN- $\gamma$, interferongamma; M, macrophage; MMP, matrix metalloproteinase; MSC, mesenchymal stromal cell; PGE2, prostaglandin E2; Th, helper T cell; Treg, regulatory T cell; TGF- $\beta$, transforming growth factor-beta]. 


\section{Conclusions}

The immunosuppressive effects of MSCs have been shown to alter the functions of several immune cells individually, the phenotypic plasticity of MSCs governed by their environment which might alter MSCs' therapeutic effect. Importantly, the stable priming of MSCs toward an immunoregulatory state should be taken into consideration while considering MSCs-based therapy for osteoarthritis of the knee.

Author Contributions: (I) Conception and design: M.J. and S.M.; (II) Administrative support: N.J., V.M.O., G.S.P. and M.K.; (III) Provision of study materials or patients: G.S.B. and Y.B.; (IV) Collection and assembly of data M.J. and S.M.; (V) Data analysis and interpretation: M.J., S.M. and N.J.; and (VI) Manuscript writing: All authors. All authors have read and agreed to the published version of the manuscript.

Funding: This research received no external funding.

Institutional Review Board Statement: Not applicable.

Informed Consent Statement: Not applicable.

Data Availability Statement: Not applicable.

Conflicts of Interest: The authors declare no conflict of interest.

\section{References}

1. Mobasheri, A.; Batt, M. An update on the pathophysiology of osteoarthritis. Ann. Phys. Rehabil. Med. 2016, 59, 333-339. [CrossRef]

2. Grässel, S.; Muschter, D. Recent advances in the treatment of osteoarthritis. F1000Research 2020, 9, 325. [CrossRef]

3. Bitton, R. The economic burden of osteoarthritis. Am. J. Manag. Care 2009, 15, S230-S235.

4. Man, G.; Mologhianu, G. Osteoarthritis pathogenesis-A complex process that involves the entire joint. J. Med. Life 2014, 7, 37-41.

5. Grässel, S.; Aszodi, A. Osteoarthritis and Cartilage Regeneration: Focus on Pathophysiology and Molecular Mechanisms. Int. J. Mol. Sci. 2019, 20, 6156. [CrossRef]

6. Cooke, M.E.; Lawless, B.M.; Jones, S.W.; Grover, L.M. Matrix degradation in osteoarthritis primes the superficial region of cartilage for mechanical damage. Acta Biomater. 2018, 78, 320-328. [CrossRef]

7. Mora, J.C.; Przkora, R.; Cruz-Almeida, Y. Knee osteoarthritis: Pathophysiology and current treatment modalities. J. Pain Res. 2018, 11, 2189-2196. [CrossRef]

8. Wojdasiewicz, P.; Poniatowski, Ł.A.; Szukiewicz, D. The Role of Inflammatory and Anti-Inflammatory Cytokines in the Pathogenesis of Osteoarthritis. Mediat. Inflamm. 2014, 2014, e561459. [CrossRef]

9. Sokolove, J.; Lepus, C.M. Role of inflammation in the pathogenesis of osteoarthritis: Latest findings and interpretations. Ther. Adv. Musculoskelet. Dis. 2013, 5, 77-94. [CrossRef]

10. Roseti, L.; Desando, G.; Cavallo, C.; Petretta, M.; Grigolo, B. Articular Cartilage Regeneration in Osteoarthritis. Cells 2019,8 , 1305. [CrossRef]

11. Jeyaraman, M.; Muthu, S.; Ganie, P.A. Does the Source of Mesenchymal Stem Cell Have an Effect in the Management of Osteoarthritis of the Knee? Meta-Analysis of Randomized Controlled Trials. Cartilage 2020, 1947603520951623. [CrossRef]

12. Muthu, S.; Jeyaraman, M.; Jain, R.; Gulati, A.; Jeyaraman, N.; Prajwal, G.S.; Mishra, P.C. Accentuating the sources of mesenchymal stem cells as cellular therapy for osteoarthritis knees-A panoramic review. Stem Cell Investig. 2021, 8. [CrossRef]

13. Zhao, L.; Kaye, A.D.; Abd-Elsayed, A. Stem Cells for the Treatment of Knee Osteoarthritis: A Comprehensive Review. Pain Physician 2018, 21, 229-242.

14. Stem cell application for osteoarthritis in the knee joint: A minireview. World J. Stem Cells 2014, 6, 629-636. [CrossRef]

15. Jeyaraman, M.; Muthu, S.; Jeyaraman, N.; Ranjan, R.; Jha, S.K.; Mishra, P. Synovium Derived Mesenchymal Stromal Cells (Sy-MSCs): A Promising Therapeutic Paradigm in the Management of Knee Osteoarthritis. JOIO 2021. [CrossRef]

16. Fitzsimmons, R.E.B.; Mazurek, M.S.; Soos, A.; Simmons, C.A. Mesenchymal Stromal/Stem Cells in Regenerative Medicine and Tissue Engineering. Stem Cells Int. 2018, 2018, e8031718. [CrossRef]

17. Murphy, M.B.; Moncivais, K.; Caplan, A.I. Mesenchymal stem cells: Environmentally responsive therapeutics for regenerative medicine. Exp. Mol. Med. 2013, 45, e54. [CrossRef]

18. Marquez-Curtis, L.A.; Janowska-Wieczorek, A.; McGann, L.E.; Elliott, J.A.W. Mesenchymal stromal cells derived from various tissues: Biological, clinical and cryopreservation aspects. Cryobiology 2015, 71, 181-197. [CrossRef]

19. Herberts, C.A.; Kwa, M.S.; Hermsen, H.P. Risk factors in the development of stem cell therapy. J. Transl. Med. 2011, 9, 29. [CrossRef]

20. Zakrzewski, W.; Dobrzyński, M.; Szymonowicz, M.; Rybak, Z. Stem cells: Past, present, and future. Stem Cell Res. Ther. 2019, 10, 68. [CrossRef]

21. Zhou, T.; Yuan, Z.; Weng, J.; Pei, D.; Du, X.; He, C.; Lai, P. Challenges and advances in clinical applications of mesenchymal stromal cells. J. Hematol. Oncol. 2021, 14, 24. [CrossRef] 
22. Lukomska, B.; Stanaszek, L.; Zuba-Surma, E.; Legosz, P.; Sarzynska, S.; Drela, K. Challenges and Controversies in Human Mesenchymal Stem Cell Therapy. Stem Cells Int. 2019, 2019, e9628536. [CrossRef]

23. Liang, X.; Ding, Y.; Zhang, Y.; Tse, H.-F.; Lian, Q. Paracrine mechanisms of mesenchymal stem cell-based therapy: Current status and perspectives. Cell Transplant. 2014, 23, 1045-1059. [CrossRef]

24. Maacha, S.; Sidahmed, H.; Jacob, S.; Gentilcore, G.; Calzone, R.; Grivel, J.-C.; Cugno, C. Paracrine Mechanisms of Mesenchymal Stromal Cells in Angiogenesis. Stem Cells Int. 2020, 2020, e4356359. [CrossRef]

25. Qi, K.; Li, N.; Zhang, Z.; Melino, G. Tissue regeneration: The crosstalk between mesenchymal stem cells and immune response. Cell Immunol. 2018, 326, 86-93. [CrossRef]

26. Costa-Almeida, R.; Calejo, I.; Gomes, M.E. Mesenchymal Stem Cells Empowering Tendon Regenerative Therapies. Int. J. Mol. Sci. 2019, 20, 3002. [CrossRef]

27. Shi, Y.; Hu, G.; Su, J.; Li, W.; Chen, Q.; Shou, P.; Xu, C.; Chen, X.; Huang, Y.; Zhu, Z.; et al. Mesenchymal stem cells: A new strategy for immunosuppression and tissue repair. Cell Res. 2010, 20, 510-518. [CrossRef]

28. Wang, M.; Yuan, Q.; Xie, L. Mesenchymal Stem Cell-Based Immunomodulation: Properties and Clinical Application. Stem Cells Int. 2018, 2018, 3057624. [CrossRef]

29. Lim, J.-Y.; Im, K.-I.; Lee, E.-S.; Kim, N.; Nam, Y.-S.; Jeon, Y.-W.; Cho, S.-G. Enhanced immunoregulation of mesenchymal stem cells by IL-10-producing type 1 regulatory T cells in collagen-induced arthritis. Sci. Rep. 2016, 6, 26851. [CrossRef]

30. Weiss, A.R.R.; Dahlke, M.H. Immunomodulation by Mesenchymal Stem Cells (MSCs): Mechanisms of Action of Living, Apoptotic, and Dead MSCs. Front. Immunol. 2019, 10, 1191. [CrossRef]

31. Ham, O.; Lee, C.Y.; Kim, R.; Lee, J.; Oh, S.; Lee, M.Y.; Kim, J.; Hwang, K.-C.; Maeng, L.-S.; Chang, W. Therapeutic Potential of Differentiated Mesenchymal Stem Cells for Treatment of Osteoarthritis. Int. J. Mol. Sci. 2015, 16, 14961-14978. [CrossRef]

32. Zhao, X.; Zhao, Y.; Sun, X.; Xing, Y.; Wang, X.; Yang, Q. Immunomodulation of MSCs and MSC-Derived Extracellular Vesicles in Osteoarthritis. Front. Bioeng. Biotechnol. 2020, 8. [CrossRef]

33. Kangari, P.; Talaei-Khozani, T.; Razeghian-Jahromi, I.; Razmkhah, M. Mesenchymal stem cells: Amazing remedies for bone and cartilage defects. Stem Cell Res. Ther. 2020, 11, 492. [CrossRef]

34. Jiang, W.; Xu, J. Immune modulation by mesenchymal stem cells. Cell Prolif. 2019, 53. [CrossRef]

35. Ankrum, J.A.; Ong, J.F.; Karp, J.M. Mesenchymal stem cells: Immune evasive, not immune privileged. Nat. Biotechnol. 2014, 32, 252-260. [CrossRef]

36. Wang, Y.; Huang, J.; Gong, L.; Yu, D.; An, C.; Bunpetch, V.; Dai, J.; Huang, H.; Zou, X.; Ouyang, H.; et al. The Plasticity of Mesenchymal Stem Cells in Regulating Surface HLA-I. iScience 2019, 15, 66-78. [CrossRef]

37. Ghannam, S.; Bouffi, C.; Djouad, F.; Jorgensen, C.; Noël, D. Immunosuppression by mesenchymal stem cells: Mechanisms and clinical applications. Stem Cell Res. Ther. 2010, 1, 2. [CrossRef]

38. Jo, C.H.; Gil Lee, Y.; Shin, W.H.; Kim, H.; Chai, J.W.; Jeong, E.C.; Kim, J.E.; Shim, H.; Shin, J.S.; Shin, I.S.; et al. Intra-articular injection of mesenchymal stem cells for the treatment of osteoarthritis of the knee: A proof-of-concept clinical trial. Stem Cells. 2014, 32, 1254-1266. [CrossRef]

39. Najar, M.; Martel-Pelletier, J.; Pelletier, J.-P.; Fahmi, H. Mesenchymal Stromal Cell Immunology for Efficient and Safe Treatment of Osteoarthritis. Front. Cell Dev. Biol. 2020, 8, 567813. [CrossRef]

40. Ma, S.; Xie, N.; Li, W.; Yuan, B.; Shi, Y.; Wang, Y. Immunobiology of mesenchymal stem cells. Cell Death Differ. 2014, 21, 216-225. [CrossRef]

41. Osińska, I.; Popko, K.; Demkow, U. Perforin: An important player in immune response. Cent. Eur. J. Immunol. 2014, 39, 109-115. [CrossRef]

42. Mancuso, P.; Murphy, M.J.; Barry, F. Immunomodulatory effect of mesenchymal stem cells following intra-articular injection in a model of osteoarthritis: A potential role for apoptosis. Osteoarthr. Cartil. 2017, 25, S386-S387. [CrossRef]

43. Ye, J.; Xie, C.; Wang, C.; Huang, J.; Yin, Z.; Heng, B.C.; Chen, X.; Shen, W. Promoting musculoskeletal system soft tissue regeneration by biomaterial-mediated modulation of macrophage polarization. Bioact. Mater. 2021, 6, 4096-4109. [CrossRef]

44. Gavin, C.; Meinke, S.; Heldring, N.; Heck, K.A.; Achour, A.; Iacobaeus, E.; Höglund, P.; Le Blanc, K.; Kadri, N. The Complement System Is Essential for the Phagocytosis of Mesenchymal Stromal Cells by Monocytes. Front. Immunol. 2019, 10, 2249. [CrossRef]

45. Hu, C.; Zhao, L.; Wu, D.; Li, L. Modulating autophagy in mesenchymal stem cells effectively protects against hypoxia- or ischemia-induced injury. Stem Cell Res. Ther. 2019, 10, 120. [CrossRef]

46. Liu, J.; Ding, Y.; Liu, Z.; Liang, X. Senescence in Mesenchymal Stem Cells: Functional Alterations, Molecular Mechanisms, and Rejuvenation Strategies. Front. Cell Dev. Biol. 2020, 8, 258. [CrossRef]

47. Fernandes, T.L.; Gomoll, A.H.; Lattermann, C.; Hernandez, A.J.; Bueno, D.F.; Amano, M.T. Macrophage: A Potential Target on Cartilage Regeneration. Front. Immunol. 2020, 11, 111. [CrossRef]

48. Wu, C.-L.; Harasymowicz, N.S.; Klimak, M.A.; Collins, K.H.; Guilak, F. The role of macrophages in osteoarthritis and cartilage repair. Osteoarthr. Cartil. 2020, 28, 544-554. [CrossRef]

49. Zhang, H.; Cai, D.; Bai, X. Macrophages regulate the progression of osteoarthritis. Osteoarthr. Cartil. 2020, 28, 555-561. [CrossRef]

50. Wu, C.-L.; McNeill, J.; Goon, K.; Little, D.; Kimmerling, K.; Huebner, J.; Kraus, V.; Guilak, F. Conditional Macrophage Depletion Increases Inflammation and Does Not Inhibit the Development of Osteoarthritis in Obese Macrophage Fas-Induced ApoptosisTransgenic Mice. Arthritis Rheumatol. 2017, 69, 1772-1783. [CrossRef] 
51. Fahy, N.; Melle, M.D.V.-V.; Lehmann, J.; Wei, W.; Grotenhuis, N.; Farrell, E.; van der Kraan, P.; Murphy, J.; Bastiaansen-Jenniskens, Y.; van Osch, G. Human osteoarthritic synovium impacts chondrogenic differentiation of mesenchymal stem cells via macrophage polarisation state. Osteoarthr. Cartil. 2014, 22, 1167-1175. [CrossRef]

52. Utomo, L.; Bastiaansen-Jenniskens, Y.; Verhaar, J.; van Osch, G. Cartilage inflammation and degeneration is enhanced by proinflammatory (M1) macrophages in vitro, but not inhibited directly by anti-inflammatory (M2) macrophages. Osteoarthr. Cartil. 2016, 24, 2162-2170. [CrossRef]

53. Hu, T.; Xu, H.; Wang, C.; Qin, H.; An, Z. Magnesium enhances the chondrogenic differentiation of mesenchymal stem cells by inhibiting activated macrophage-induced inflammation. Sci. Rep. 2018, 8, 3406. [CrossRef]

54. Chen, Y.; Jiang, W.; Yong, H.; He, M.; Yang, Y.; Deng, Z.; Li, Y. Macrophages in osteoarthritis: Pathophysiology and therapeutics. Am. J. Transl. Res. 2020, 12, 261-268.

55. Zheng, G.; Ge, M.; Qiu, G.; Shu, Q.; Xu, J. Mesenchymal Stromal Cells Affect Disease Outcomes via Macrophage Polarization. Stem Cells Int. 2015, 2015, 989473. [CrossRef]

56. Vasandan, A.B.; Jahnavi, S.; Shashank, C.; Prasad, P.; Kumar, A.; Prasanna, S.J. Human Mesenchymal stem cells program macrophage plasticity by altering their metabolic status via a PGE 2-dependent mechanism. Sci. Rep. 2016, 6, 38308. [CrossRef]

57. Bernardo, M.E.; Fibbe, W.E. Mesenchymal Stromal Cells: Sensors and Switchers of Inflammation. Cell Stem Cell 2013, 13, 392-402. [CrossRef]

58. Saldaña, L.; Bensiamar, F.; Vallés, G.; Mancebo, F.J.; García-Rey, E.; Vilaboa, N. Immunoregulatory potential of mesenchymal stem cells following activation by macrophage-derived soluble factors. Stem Cell Res. Ther. 2019, 10, 58. [CrossRef]

59. Li, H.; Shen, S.; Fu, H.; Wang, Z.; Li, X.; Sui, X.; Yuan, M.; Liu, S.; Wang, G.; Guo, Q. Immunomodulatory Functions of Mesenchymal Stem Cells in Tissue Engineering. Stem Cells Int. 2019, 2019, e9671206. [CrossRef]

60. Stevens, H.Y.; Bowles, A.C.; Yeago, C.; Roy, K. Molecular Crosstalk Between Macrophages and Mesenchymal Stromal Cells. Front. Cell Dev. Biol. 2020, 8, 600160. [CrossRef]

61. Ko, J.H.; Kim, H.J.; Jeong, H.J.; Lee, H.J.; Oh, J.Y. Mesenchymal Stem and Stromal Cells Harness Macrophage-Derived Amphiregulin to Maintain Tissue Homeostasis. Cell Rep. 2020, 30, 3806-3820.e6. [CrossRef]

62. Li, N.; Gao, J.; Mi, L.; Zhang, G.; Zhang, L.; Zhang, N.; Huo, R.; Hu, J.; Xu, K. Synovial membrane mesenchymal stem cells: Past life, current situation, and application in bone and joint diseases. Stem Cell Res. Ther. 2020, 11, 381. [CrossRef]

63. Kay, A.G.; Long, G.; Tyler, G.; Stefan, A.; Broadfoot, S.J.; Piccinini, A.M.; Middleton, J.; Kehoe, O. Mesenchymal Stem CellConditioned Medium Reduces Disease Severity and Immune Responses in Inflammatory Arthritis. Sci. Rep. 2017, 7, 18019. [CrossRef]

64. Rosshirt, N.; Hagmann, S.; Tripel, E.; Gotterbarm, T.; Kirsch, J.; Zeifang, F.; Lorenz, H.; Tretter, T.; Moradi, B. A predominant Th1 polarization is present in synovial fluid of end-stage osteoarthritic knee joints: Analysis of peripheral blood, synovial fluid and synovial membrane. Clin. Exp. Immunol. 2019, 195, 395-406. [CrossRef]

65. Li, Y.; Luo, W.; Zhu, S.; Lei, G. T Cells in Osteoarthritis: Alterations and Beyond. Front. Immunol. 2017, 8, 356. [CrossRef]

66. Pelletier, M.; Maggi, L.; Micheletti, A.; Lazzeri, E.; Tamassia, N.; Costantini, C.; Cosmi, L.; Lunardi, C.; Annunziato, F.; Romagnani, S.; et al. Evidence for a cross-talk between human neutrophils and Th17 cells. Blood 2010, 115, 335-343. [CrossRef]

67. Kato, H.; Endres, J.; Fox, D.A. The roles of IFN- $\gamma$ versus IL-17 in pathogenic effects of human Th17 cells on synovial fibroblasts. Mod. Rheumatol. 2013, 23, 1140-1150. [CrossRef]

68. Hussein, M.R.; Fathi, N.A.; El-Din, A.M.E.; Hassan, H.I.; Abdullah, F.; Al-Hakeem, E.; Backer, E.A. Alterations of the CD4+, CD8+ T Cell Subsets, Interleukins-1 $\beta$, IL-10, IL-17, Tumor Necrosis Factor- $\alpha$ and Soluble Intercellular Adhesion Molecule-1 in Rheumatoid Arthritis and Osteoarthritis: Preliminary Observations. Pathol. Oncol. Res. 2008, 14, 321-328. [CrossRef]

69. Pawłowska, J.; Mikosik, A.; Soroczynska-Cybula, M.; Jozwik, A.; Łuczkiewicz, P.; Mazurkiewicz, S.; Lorczyński, A.; Witkowski, J.M.; Bryl, E. Different distribution of CD4 and CD8 T cells in synovial membrane and peripheral blood of rheumatoid arthritis and osteoarthritis patients. Folia Histochem. Cytobiol. 2009, 47, 627-632. [CrossRef]

70. Hsieh, J.-L.; Shiau, A.-L.; Lee, C.-H.; Yang, S.-J.; Lee, B.-O.; Jou, I.-M.; Wu, C.-L.; Chen, S.-H.; Shen, P.-C. CD8+ T Cell-Induced Expression of Tissue Inhibitor of Metalloproteinses-1 Exacerbated Osteoarthritis. Int. J. Mol. Sci. 2013, 14, 19951-19970. [CrossRef]

71. Corthay, A. How do Regulatory T Cells Work? Scand. J. Immunol. 2009, 70, 326-336. [CrossRef]

72. Sakaguchi, S.; Yamaguchi, T.; Nomura, T.; Ono, M. Regulatory T Cells and Immune Tolerance. Cell 2008, 133, 775-787. [CrossRef]

73. Duffy, M.M.; Ritter, T.; Ceredig, R.; Griffin, M.D. Mesenchymal stem cell effects on T-cell effector pathways. Stem Cell Res. Ther. 2011, 2, 34. [CrossRef]

74. Chen, Q.-H.; Wu, F.; Liu, L.; Chen, H.-B.; Zheng, R.-Q.; Wang, H.-L.; Yu, L.-N. Mesenchymal stem cells regulate the Th17/Treg cell balance partly through hepatocyte growth factor in vitro. Stem Cell Res. Ther. 2020, 11, 91. [CrossRef]

75. Romano, M.; Fanelli, G.; Albany, C.J.; Giganti, G.; Lombardi, G. Past, Present, and Future of Regulatory T Cell Therapy in Transplantation and Autoimmunity. Front. Immunol. 2019, 10, 43. [CrossRef]

76. Rana, J.; Biswas, M. Regulatory T cell therapy: Current and future design perspectives. Cell. Immunol. 2020, $356,104193$. [CrossRef]

77. Tsukiyama, T.; Ishida, N.; Shirane, M.; Minamishima, Y.A.; Hatakeyama, S.; Kitagawa, M.; Nakayama, K.; Nakayama, K.-I. Down-Regulation of p27Kip1 Expression Is Required for Development and Function of T Cells. J. Immunol. 2001, 166, 304-312. [CrossRef] 
78. Kickler, K.; Maltby, K.; Ni Choileain, S.; Stephen, J.; Wright, S.; Hafler, D.A.; Jabbour, H.N.; Astier, A.L. Prostaglandin E2 affects T cell responses through modulation of CD46 expression. J. Immunol. 2012, 188, 5303-5310. [CrossRef]

79. Ren, G.; Zhao, X.; Zhang, L.; Zhang, J.; L’Huillier, A.; Ling, W.; Roberts, A.I.; Le, A.D.; Shi, S.; Shao, C.; et al. Inflammatory Cytokine-Induced Intercellular Adhesion Molecule-1 and Vascular Cell Adhesion Molecule-1 in Mesenchymal Stem Cells Are Critical for Immunosuppression. J. Immunol. 2010, 184, 2321-2328. [CrossRef]

80. Ren, G.; Roberts, A.I.; Shi, Y. Adhesion molecules: Key players in Mesenchymal stem cell-mediated immunosuppression. Cell Adhes. Migr. 2011, 5, 20-22. [CrossRef]

81. Brandstadter, J.D.; Maillard, I. Notch signalling in T cell homeostasis and differentiation. Open Biol. 2019, 9, 190187. [CrossRef]

82. Yamada, A.; Arakaki, R.; Saito, M.; Kudo, Y.; Ishimaru, N. Dual Role of Fas/FasL-Mediated Signal in Peripheral Immune Tolerance. Front. Immunol. 2017, 8, 403. [CrossRef]

83. Crawford, P.L.; Noël, D.; Fernandez, X.; Khoury, M.; Figueroa, F.E.; Carrión, F.; Jorgensen, C.; Djouad, F. Mesenchymal stem cells repress Th17 molecular program through the PD-1 pathway. PLoS ONE 2012, 7, e45272. [CrossRef]

84. De Cássia Noronha, N.; Mizukami, A.; Caliári-Oliveira, C.; Cominal, J.G.; Rocha, J.L.M.; Covas, D.T.; Swiech, K.; Malmegrim, K.C.R. Priming approaches to improve the efficacy of mesenchymal stromal cell-based therapies. Stem Cell Res. Ther. 2019, 10, 131. [CrossRef]

85. Liu, J.; Liu, Q.; Chen, X. The Immunomodulatory Effects of Mesenchymal Stem Cells on Regulatory B Cells. Front. Immunol. 2020, 11, 1843. [CrossRef]

86. Fan, L.; Hu, C.; Chen, J.; Cen, P.; Wang, J.; Li, L. Interaction between Mesenchymal Stem Cells and B-Cells. Int. J. Mol. Sci. 2016, 17, 650. [CrossRef]

87. Corcione, A.; Benvenuto, F.; Ferretti, E.; Giunti, D.; Cappiello, V.; Cazzanti, F.; Risso, M.; Gualandi, F.; Mancardi, G.L.; Pistoia, V.; et al. Human mesenchymal stem cells modulate B-cell functions. Blood 2006, 107, 367-372. [CrossRef]

88. Ungerer, C.; Quade-Lyssy, P.; Radeke, H.; Henschler, R.; Königs, C.; Koehl, U.; Seifried, E.; Schuettrumpf, J. Galectin-9 Is a Suppressor of T and B Cells and Predicts the Immune Modulatory Potential of Mesenchymal Stromal Cell Preparations. Stem Cells Dev. 2014, 23, 755-766. [CrossRef]

89. Sáez de Guinoa, J.; Barrio, L.; Mellado, M.; Carrasco, Y.R. CXCL13/CXCR5 signaling enhances BCR-triggered B-cell activation by shaping cell dynamics. Blood 2011, 118, 1560-1569. [CrossRef]

90. Liu, S.; Liu, F.; Zhou, Y.; Jin, B.; Sun, Q.; Guo, S. Immunosuppressive Property of MSCs Mediated by Cell Surface Receptors. Front. Immunol. 2020, 11, 1076. [CrossRef]

91. Chen, X.; Cai, C.; Xu, D.; Liu, Q.; Zheng, S.; Liu, L.; Li, G.; Zhang, X.; Li, X.; Ma, Y.; et al. Human Mesenchymal Stem Cell-Treated Regulatory CD23+CD43+ B Cells Alleviate Intestinal Inflammation. Theranostics 2019, 9, 4633-4647. [CrossRef]

92. Carreras-Planella, L.; Monguió-Tortajada, M.; Borràs, F.E.; Franquesa, M. Corrigendum: Immunomodulatory Effect of MSC on B Cells Is Independent of Secreted Extracellular Vesicles. Front. Immunol. 2019, 10, 2413. [CrossRef]

93. Rafei, M.; Hsieh, J.; Fortier, S.; Li, M.; Yuan, S.; Birman, E.; Forner, K.; Boivin, M.-N.; Doody, K.; Tremblay, M.; et al. Mesenchymal stromal cell-derived CCL2 suppresses plasma cell immunoglobulin production via STAT3 inactivation and PAX5 induction. Blood 2008, 112, 4991-4998. [CrossRef]

94. Schena, F.; Gambini, C.; Gregorio, A.; Mosconi, M.; Reverberi, D.; Gattorno, M.; Casazza, S.; Uccelli, A.; Moretta, L.; Martini, A.; et al. Interferon- $\gamma$-dependent inhibition of B cell activation by bone marrow-derived mesenchymal stem cells in a murine model of systemic lupus erythematosus. Arthritis Rheum. 2010, 62, 2776-2786. [CrossRef]

95. Catalán, D.; Mansilla, M.A.; Ferrier, A.; Soto, L.; Oleinika, K.; Aguillón, J.C.; Aravena, O. Immunosuppressive Mechanisms of Regulatory B Cells. Front. Immunol. 2021, 12, 611795. [CrossRef]

96. Bohacova, P.; Kossl, J.; Hajkova, M.; Hermankova, B.; Javorkova, E.; Zajicova, A.; Krulova, M.; Holan, V. Interleukin-10 production by B cells is regulated by cytokines, but independently of GATA-3 or FoxP3 expression. Cell Immunol. 2020, 347, 103987. [CrossRef]

97. Vivier, E.; Tomasello, E.; Baratin, M.; Walzer, T.; Ugolini, S. Functions of natural killer cells. Nat. Immunol. 2008, 9, 503-510. [CrossRef]

98. Ma, O.K.-F.; Chan, K.H. Immunomodulation by mesenchymal stem cells: Interplay between mesenchymal stem cells and regulatory lymphocytes. World J. Stem Cells 2016, 8, 268-278. [CrossRef]

99. Spaggiari, G.M.; Capobianco, A.; Becchetti, S.; Mingari, M.C.; Moretta, L. Mesenchymal stem cell-natural killer cell interactions: Evidence that activated NK cells are capable of killing MSCs, whereas MSCs can inhibit IL-2-induced NK-cell proliferation. Blood 2006, 107, 1484-1490. [CrossRef]

100. Malhotra, A.; Shanker, A. NK cells: Immune cross-talk and therapeutic implications. Immunotherapy 2011, 3, 1143-1166. [CrossRef]

101. Castro-Manrreza, M.E.; Montesinos, J.J. Immunoregulation by Mesenchymal Stem Cells: Biological Aspects and Clinical Applications. J. Immunol. Res. 2015, 2015, e394917. [CrossRef]

102. Uccelli, A.; Moretta, L.; Pistoia, V. Immunoregulatory function of mesenchymal stem cells. Eur. J. Immunol. 2006, 36, 2566-2573. [CrossRef]

103. Sotiropoulou, P.A.; Perez, S.A.; Gritzapis, A.D.; Baxevanis, C.N.; Papamichail, M. Interactions between human mesenchymal stem cells and natural killer cells. Stem Cells 2006, 24, 74-85. [CrossRef]

104. Shi, Y.; Su, J.; Roberts, A.I.; Shou, P.; Rabson, A.B.; Ren, G. How mesenchymal stem cells interact with tissue immune responses. Trends Immunol. 2012, 33, 136-143. [CrossRef] 
105. Tosello-Trampont, A.; Surette, F.A.; Ewald, S.E.; Hahn, Y.S. Immunoregulatory Role of NK Cells in Tissue Inflammation and Regeneration. Front. Immunol. 2017, 8, 301. [CrossRef]

106. de Lange-Brokaar, B.; Ioan-Facsinay, A.; van Osch, G.; Zuurmond, A.-M.; Schoones, J.W.; Toes, R.; Huizinga, T.; Kloppenburg, M. Synovial inflammation, immune cells and their cytokines in osteoarthritis: A review. Osteoarthr. Cartil. 2012, 20, 1484-1499. [CrossRef]

107. Jaime, P.; García-Guerrero, N.; Estella, R.; Pardo, J.; García-Álvarez, F.; Martinez-Lostao, L. CD56+/CD16- Natural Killer cells expressing the inflammatory protease granzyme A are enriched in synovial fluid from patients with osteoarthritis. Osteoarthr. Cartil. 2017, 25, 1708-1718. [CrossRef]

108. Ferlazzo, G.; Klein, J.; Paliard, X.; Wei, W.Z.; Galy, A. Dendritic cells generated from CD34+ progenitor cells with flt3 ligand, c-kit ligand, GM-CSF, IL-4, and TNF-alpha are functional antigen-presenting cells resembling mature monocyte-derived dendritic cells. J. Immunother. 2000, 23, 48-58. [CrossRef]

109. Lutz, M.B.; Strobl, H.; Schuler, G.; Romani, N. GM-CSF Monocyte-Derived Cells and Langerhans Cells As Part of the Dendritic Cell Family. Front. Immunol. 2017, 8, 1388. [CrossRef]

110. Pennock, N.D.; White, J.T.; Cross, E.W.; Cheney, E.E.; Tamburini, B.A.; Kedl, R.M. T cell responses: Naïve to memory and everything in between. Adv. Physiol. Educ. 2013, 37, 273-283. [CrossRef]

111. Jiang, X.-X.; Zhang, Y.; Liu, B.; Zhang, S.-X.; Wu, Y.; Yu, X.-D.; Mao, N. Human mesenchymal stem cells inhibit differentiation and function of monocyte-derived dendritic cells. Blood 2005, 105, 4120-4126. [CrossRef]

112. Spaggiari, G.M.; Abdelrazik, H.; Becchetti, F.; Moretta, L. MSCs inhibit monocyte-derived DC maturation and function by selectively interfering with the generation of immature DCs: Central role of MSC-derived prostaglandin E2. Blood 2009, 113, 6576-6583. [CrossRef]

113. Aggarwal, S.; Pittenger, M.F. Human mesenchymal stem cells modulate allogeneic immune cell responses. Blood 2005, 105, 1815-1822. [CrossRef]

114. Zhang, X.; Tu, H.; Yang, Y.; Fang, L.; Wu, Q.; Li, J. Mesenchymal Stem Cell-Derived Extracellular Vesicles: Roles in Tumor Growth, Progression, and Drug Resistance. Stem Cells Int. 2017, 2017, e1758139. [CrossRef]

115. Muthu, S.; Bapat, A.; Jain, R.; Jeyaraman, N.; Jeyaraman, M. Exosomal therapy-a new frontier in regenerative medicine. Stem Cell Investig. 2021, 8, 7. [CrossRef]

116. Hassanzadeh, A.; Rahman, H.S.; Markov, A.; Endjun, J.J.; Zekiy, A.O.; Chartrand, M.S.; Beheshtkhoo, N.; Kouhbanani, M.A.J.; Marofi, F.; Nikoo, M.; et al. Mesenchymal stem/stromal cell-derived exosomes in regenerative medicine and cancer; overview of development, challenges, and opportunities. Stem Cell Res. Ther. 2021, 12, 297. [CrossRef]

117. Jeyaraman, M.; Muthu, S.; Gulati, A.; Jeyaraman, N.; Prajwal, G.S.; Jain, R. Mesenchymal Stem Cell-Derived Exosomes: A Potential Therapeutic Avenue in Knee Osteoarthritis. Cartilage 2020, 1947603520962567. [CrossRef]

118. Ha, D.; Yang, N.; Nadithe, V. Exosomes as therapeutic drug carriers and delivery vehicles across biological membranes: Current perspectives and future challenges. Acta Pharm. Sin. B 2016, 6, 287-296. [CrossRef]

119. Seo, N.; Akiyoshi, K.; Shiku, H. Exosome-mediated regulation of tumor immunology. Cancer Sci. 2018, 109, 2998-3004. [CrossRef]

120. Cheng, A.; Choi, D.; Lora, M.; Shum-Tim, D.; Rak, J.; Colmegna, I. Human multipotent mesenchymal stromal cells cytokine priming promotes RAB27B-regulated secretion of small extracellular vesicles with immunomodulatory cargo. Stem Cell Res. Ther. 2020, 11, 539. [CrossRef]

121. Ramos, T.L.; Sánchez-Abarca, L.I.; Muntión, S.; Preciado, S.; Puig, N.; López-Ruano, G.; Hernández-Hernández, Á.; Redondo, A.; Ortega, R.; Rodríguez, C.; et al. MSC surface markers (CD44, CD73, and CD90) can identify human MSC-derived extracellular vesicles by conventional flow cytometry. Cell Commun. Signal. 2016, 14, 2. [CrossRef]

122. Doyle, L.M.; Wang, M.Z. Overview of Extracellular Vesicles, Their Origin, Composition, Purpose, and Methods for Exosome Isolation and Analysis. Cells 2019, 8, 727. [CrossRef]

123. Margolis, L.; Sadovsky, Y. The biology of extracellular vesicles: The known unknowns. PLoS Biol. 2019, 17, e3000363. [CrossRef] [PubMed]

124. Buzás, E.I.; Tóth, E.Á.; Sódar, B.W.; Szabó-Taylor, K.É. Molecular interactions at the surface of extracellular vesicles. Semin. Immunopathol. 2018, 40, 453-464. [CrossRef] [PubMed]

125. Zhang, Y.; Liu, Y.; Liu, H.; Tang, W.H. Exosomes: Biogenesis, biologic function and clinical potential. Cell Biosci. 2019, 9, 19. [CrossRef]

126. Đokić, J.M.; Tomić, S.Z.; Čolić, M.J. Cross-Talk Between Mesenchymal Stem/Stromal Cells and Dendritic Cells. Curr. Stem Cell Res. Ther. 2016, 11, 51-65. [CrossRef] [PubMed]

127. Harrell, C.R.; Djonov, V.; Volarevic, V. The Cross-Talk between Mesenchymal Stem Cells and Immune Cells in Tissue Repair and Regeneration. Int. J. Mol. Sci. 2021, 22, 2472. [CrossRef]

128. Asgarpour, K.; Shojaei, Z.; Amiri, F.; Ai, J.; Mahjoubin-Tehran, M.; Ghasemi, F.; ArefNezhad, R.; Hamblin, M.R.; Mirzaei, H. Exosomal microRNAs derived from mesenchymal stem cells: Cell-to-cell messages. Cell Commun. Signal. 2020, 18, 149. [CrossRef]

129. Liu, J.; Chen, T.; Lei, P.; Tang, X.; Huang, P. Exosomes Released by Bone Marrow Mesenchymal Stem Cells Attenuate Lung Injury Induced by Intestinal Ischemia Reperfusion via the TLR4/NF-kB Pathway. Int. J. Med. Sci. 2019, 16, 1238-1244. [CrossRef]

130. Terraza-Aguirre, C.; Campos-Mora, M.; Elizondo-Vega, R.; Contreras-López, R.; Luz-Crawford, P.; Jorgensen, C.; Djouad, F. Mechanisms behind the Immunoregulatory Dialogue between Mesenchymal Stem Cells and Th17 Cells. Cells 2020, 9, 1660. [CrossRef] 
131. Julier, Z.; Park, A.J.; Briquez, P.S.; Martino, M.M. Promoting tissue regeneration by modulating the immune system. Acta Biomater. 2017, 53, 13-28. [CrossRef] [PubMed]

132. García-Bernal, D.; García-Arranz, M.; Yáñez, R.M.; Hervás-Salcedo, R.; Cortés, A.; Fernández-García, M.; Hernando-Rodríguez, M.; Quintana-Bustamante, Ó.; Bueren, J.A.; García-Olmo, D.; et al. The Current Status of Mesenchymal Stromal Cells: Controversies, Unresolved Issues and Some Promising Solutions to Improve Their Therapeutic Efficacy. Front. Cell Dev. Biol. 2021, 9, 650664. [CrossRef] [PubMed]

133. Wang, Y.; Zhao, M.; Liu, S.; Guo, J.; Lu, Y.; Cheng, J.; Liu, J. Macrophage-derived extracellular vesicles: Diverse mediators of pathology and therapeutics in multiple diseases. Cell Death Dis. 2020, 11, 924. [CrossRef]

134. Tung, S.L.; Boardman, D.A.; Sen, M.; Letizia, M.; Peng, Q.; Cianci, N.; Dioni, L.; Carlin, L.; Lechler, R.; Bollati, V.; et al. Regulatory T cell-derived extracellular vesicles modify dendritic cell function. Sci. Rep. 2018, 8, 6065. [CrossRef]

135. Essandoh, K.; Li, Y.; Huo, J.; Fan, G.-C. MiRNA-Mediated Macrophage Polarization and Its Potential Role in the Regulation of Inflammatory Response. Shock 2016, 46, 122-131. [CrossRef]

136. Huang, C.; Liu, X.-J.; Zhou, Q.; Xie, J.; Ma, T.-T.; Meng, X.-M.; Li, J. MiR-146a modulates macrophage polarization by inhibiting Notch1 pathway in RAW264.7 macrophages. Int. Immunopharmacol. 2016, 32, 46-54. [CrossRef] [PubMed]

137. Fan, X.-L.; Zhang, Y.; Li, X.; Fu, Q.-L. Mechanisms underlying the protective effects of mesenchymal stem cell-based therapy. Cell Mol. Life Sci. 2020, 77, 2771-2794. [CrossRef]

138. Melo, S.A.; Luecke, L.B.; Kahlert, C.; Fernandez, A.F.; Gammon, S.T.; Kaye, J.; LeBleu, V.S.; Mittendorf, E.A.; Weitz, J.; Rahbari, N.; et al. Glypican-1 identifies cancer exosomes and detects early pancreatic cancer. Nature 2015, 523, 177-182. [CrossRef] [PubMed]

139. Kawakami, K.; Fujita, Y.; Matsuda, Y.; Arai, T.; Horie, K.; Kameyama, K.; Kato, T.; Masunaga, K.; Kasuya, Y.; Tanaka, M.; et al. Gamma-glutamyltransferase activity in exosomes as a potential marker for prostate cancer. BMC Cancer 2017, 17, 316. [CrossRef]

140. Kolhe, R.; Hunter, M.; Liu, S.; Jadeja, R.N.; Pundkar, C.; Mondal, A.K.; Mendhe, B.; Drewry, M.; Rojiani, M.V.; Liu, Y.; et al Gender-specific differential expression of exosomal miRNA in synovial fluid of patients with osteoarthritis. Sci. Rep. 2017, 7, 2029. [CrossRef]

141. van Spil, W.E.; DeGroot, J.; Lems, W.F.; Oostveen, J.C.M.; Lafeber, F.P.J.G. Serum and urinary biochemical markers for knee and hip-osteoarthritis: A systematic review applying the consensus BIPED criteria. Osteoarthr. Cartil. 2010, 18, 605-612. [CrossRef]

142. Işın, M.; Uysaler, E.; Özgür, E.; Köseoğlu, H.; Şanlı, Ö.; Yücel, Ö.B.; Gezer, U.; Dalay, N. Exosomal lncRNA-p21 levels may help to distinguish prostate cancer from benign disease. Front. Genet. 2015, 6. [CrossRef]

143. Zhao, C.; Chen, J.-Y.; Peng, W.-M.; Yuan, B.; Bi, Q.; Xu, Y.-J. Exosomes from adipose-derived stem cells promote chondrogenesis and suppress inflammation by upregulating miR-145 and miR-221. Mol. Med. Rep. 2020, 21, 1881-1889. [CrossRef]

144. Rabinowits, G.; Gerçel-Taylor, C.; Day, J.M.; Taylor, D.D.; Kloecker, G.H. Exosomal microRNA: A diagnostic marker for lung cancer. Clin. Lung Cancer 2009, 10, 42-46. [CrossRef]

145. Lv, L.-L.; Cao, Y.-H.; Ni, H.-F.; Xu, M.; Liu, D.; Liu, H.; Chen, P.-S.; Liu, B.-C. MicroRNA-29c in urinary exosome/microvesicle as a biomarker of renal fibrosis. Am. J. Physiol. Physiol. 2013, 305, F1220-F1227. [CrossRef]

146. Song, J.; Kim, D.; Han, J.; Kim, Y.; Lee, M.; Jin, E.-J. PBMC and exosome-derived Hotair is a critical regulator and potent marker for rheumatoid arthritis. Clin. Exp. Med. 2015, 15, 121-126. [CrossRef] [PubMed]

147. Zhang, S.; Teo, K.Y.W.; Chuah, S.J.; Lai, R.C.; Lim, S.K.; Toh, W.S. MSC exosomes alleviate temporomandibular joint osteoarthritis by attenuating inflammation and restoring matrix homeostasis. Biomaterials 2019, 200, 35-47. [CrossRef]

148. Zhu, S.; Zhu, J.; Zhen, G.; Hu, Y.; An, S.; Li, Y.; Zheng, Q.; Chen, Z.; Yang, Y.; Wan, M.; et al. Subchondral bone osteoclasts induce sensory innervation and osteoarthritis pain. J. Clin. Investig. 2019, 129, 1076-1093. [CrossRef]

149. Chen, Y.; Lin, S.; Sun, Y.; Guo, J.; Lu, Y.; Suen, C.; Zhang, J.; Zha, Z.; Ho, K.; Pan, X.; et al. Attenuation of subchondral bone abnormal changes in osteoarthritis by inhibition of SDF-1 signaling. Osteoarthr. Cartil. 2017, 25, 986-994. [CrossRef] [PubMed]

150. Xu, T.; Xu, M.; Bai, J.; Lin, J.; Yu, B.; Liu, Y.; Guo, X.; Shen, J.; Sun, H.; Hao, Y.; et al. Tenocyte-derived exosomes induce the tenogenic differentiation of mesenchymal stem cells through TGF- $\beta$. Cytotechnology 2019, 71, 57-65. [CrossRef]

151. Yao, Y.; Chen, R.; Wang, G.; Zhang, Y.; Liu, F. Exosomes derived from mesenchymal stem cells reverse EMT via TGF- $\beta 1 /$ Smad pathway and promote repair of damaged endometrium. Stem Cell Res. Ther. 2019, 10, 225. [CrossRef] [PubMed]

152. Mao, G.; Hu, S.; Zhang, Z.; Wu, P.; Zhao, X.; Lin, R.; Liao, W.; Kang, Y. Exosomal miR-95-5p regulates chondrogenesis and cartilage degradation via histone deacetylase 2/8. J. Cell. Mol. Med. 2018, 22, 5354-5366. [CrossRef] [PubMed]

153. Zhao, Y.; Xu, J. Synovial fluid-derived exosomal lncRNA PCGEM1 as biomarker for the different stages of osteoarthritis. Int. Orthop. 2018, 42, 2865-2872. [CrossRef]

154. Yang, S.; Kim, J.; Ryu, J.-H.; Oh, H.; Chun, C.-H.; Kim, B.J.; Min, B.H.; Chun, J.-S. Hypoxia-inducible factor-2 $\alpha$ is a catabolic regulator of osteoarthritic cartilage destruction. Nat. Med. 2010, 16, 687-693. [CrossRef] [PubMed]

155. Zhu, Y.; Wang, Y.; Zhao, B.; Niu, X.; Hu, B.; Li, Q.; Zhang, J.; Ding, J.; Chen, Y.; Wang, Y. Comparison of exosomes secreted by induced pluripotent stem cell-derived mesenchymal stem cells and synovial membrane-derived mesenchymal stem cells for the treatment of osteoarthritis. Stem Cell Res. Ther. 2017, 8, 64. [CrossRef]

156. Mao, G.; Zhang, Z.; Hu, S.; Zhang, Z.; Chang, Z.; Huang, Z.; Liao, W.; Kang, Y. Exosomes derived from miR-92a-3p-overexpressing human mesenchymal stem cells enhance chondrogenesis and suppress cartilage degradation via targeting WNT5A. Stem Cell Res. Ther. 2018, 9, 247. [CrossRef]

157. Sun, H.; Hu, S.; Zhang, Z.; Lun, J.; Liao, W.; Zhang, Z. Expression of exosomal microRNAs during chondrogenic differentiation of human bone mesenchymal stem cells. J. Cell Biochem. 2019, 120, 171-181. [CrossRef] [PubMed] 
158. Huang, X.; Qiao, F.; Xue, P. The protective role of microRNA-140-5p in synovial injury of rats with knee osteoarthritis via inactivating the TLR4/Myd88/NF- $\mathrm{KB}$ signaling pathway. Cell Cycle 2019, 18, 2344-2358. [CrossRef]

159. Liu, Y.; Lin, L.; Zou, R.; Wen, C.; Wang, Z.; Lin, F. MSC-derived exosomes promote proliferation and inhibit apoptosis of chondrocytes via lncRNA-KLF3-AS1/miR-206/GIT1 axis in osteoarthritis. Cell Cycle 2018, 17, 2411-2422. [CrossRef]

160. Qi, H.; Liu, D.P.; Xiao, D.W.; Tian, D.C.; Su, Y.W.; Jin, S.F. Exosomes derived from mesenchymal stem cells inhibit mitochondrial dysfunction-induced apoptosis of chondrocytes via p38, ERK, and Akt pathways. In Vitro Cell Dev. Biol. Anim. 2019, 55, 203-210. [CrossRef]

161. Tofiño-Vian, M.; Guillén, M.I.; Pérez Del Caz, M.D.; Silvestre, A.; Alcaraz, M.J. Microvesicles from Human Adipose Tissue-Derived Mesenchymal Stem Cells as a New Protective Strategy in Osteoarthritic Chondrocytes. Cell. Physiol. Biochem. 2018, 47, 11-25. [CrossRef] [PubMed]

162. Tofiño-Vian, M.; Guillén, M.I.; Pérez Del Caz, M.D.; Castejón, M.A.; Alcaraz, M.J. Extracellular Vesicles from Adipose-Derived Mesenchymal Stem Cells Downregulate Senescence Features in Osteoarthritic Osteoblasts. Oxid. Med. Cell. Longev. 2017, 2017, 7197598. [CrossRef] [PubMed]

163. Cosenza, S.; Ruiz, M.; Toupet, K.; Jorgensen, C.; Noël, D. Mesenchymal stem cells derived exosomes and microparticles protect cartilage and bone from degradation in osteoarthritis. Sci. Rep. 2017, 7, 16214. [CrossRef]

164. Wang, Y.; Yu, D.; Liu, Z.; Zhou, F.; Dai, J.; Wu, B.; Zhou, J.; Heng, B.C.; Zhou, X.H.; Ouyang, H.; et al. Exosomes from embryonic mesenchymal stem cells alleviate osteoarthritis through balancing synthesis and degradation of cartilage extracellular matrix. Stem Cell Res. Ther. 2017, 8, 189. [CrossRef]

165. Kyurkchiev, D.; Bochev, I.; Ivanova-Todorova, E.; Mourdjeva, M.; Oreshkova, T.; Belemezova, K.; Kyurkchiev, S. Secretion of immunoregulatory cytokines by mesenchymal stem cells. World J. Stem Cells 2014, 6, 552-570. [CrossRef] [PubMed]

166. Zhao, Q.; Ren, H.; Han, Z. Mesenchymal stem cells: Immunomodulatory capability and clinical potential in immune diseases. J. Cell. Immunother. 2016, 2, 3-20. [CrossRef]

167. Hofer, H.R.; Tuan, R.S. Secreted trophic factors of mesenchymal stem cells support neurovascular and musculoskeletal therapies. Stem Cell Res.Ther. 2016, 7, 131. [CrossRef]

168. Pittenger, M.F.; Discher, D.E.; Péault, B.M.; Phinney, D.G.; Hare, J.M.; Caplan, A.I. Mesenchymal stem cell perspective: Cell biology to clinical progress. npj Regen. Med. 2019, 4, 1-15. [CrossRef]

169. Chinnadurai, R.; Copland, I.B.; Patel, S.R.; Galipeau, J. IDO-independent suppression of T cell effector function by IFN- $\gamma$-licensed human mesenchymal stromal cells. J. Immunol. 2014, 192, 1491-1501. [CrossRef]

170. Luz-Crawford, P.; Kurte, M.; Bravo-Alegría, J.; Contreras, R.; Nova-Lamperti, E.; Tejedor, G.; Noël, D.; Jorgensen, C.; Figueroa, F.; Djouad, F.; et al. Mesenchymal stem cells generate a CD4+CD25+Foxp3+ regulatory $\mathrm{T}$ cell population during the differentiation process of Th1 and Th17 cells. Stem Cell Res. Ther. 2013, 4, 65. [CrossRef]

171. Haddad, R.; Saldanha-Araujo, F. Mechanisms of T-Cell Immunosuppression by Mesenchymal Stromal Cells: What Do We Know So Far? BioMed Res.Int. 2014, 2014, e216806. [CrossRef] [PubMed]

172. Metcalfe, S.M. LIF in the regulation of T-cell fate and as a potential therapeutic. Genes Immun. 2011, 12, 157-168. [CrossRef] [PubMed]

173. Wink, D.A.; Hines, H.B.; Cheng, R.Y.S.; Switzer, C.H.; Flores-Santana, W.; Vitek, M.P.; Ridnour, L.A.; Colton, C.A. Nitric oxide and redox mechanisms in the immune response. J. Leukoc. Biol. 2011, 89, 873-891. [CrossRef] [PubMed] 